\title{
Measles Vaccine
}

\author{
Diane E. Griffin
}

\begin{abstract}
Measles remains an important cause of child morbidity and mortality worldwide despite the availability of a safe and efficacious vaccine. The current measles virus $(\mathrm{MeV})$ vaccine was developed empirically by attenuation of wild-type (WT) MeV by in vitro passage in human and chicken cells and licensed in 1963. Additional passages led to further attenuation and the successful vaccine strains in widespread use today. Attenuation is associated with decreased replication in lymphoid tissue, but the molecular basis for this restriction has not been identified. The immune response is age dependent, inhibited by maternal antibody $(\mathrm{Ab})$ and involves induction of both $\mathrm{Ab}$ and $\mathrm{T}$ cell responses that resemble the responses to WT MeV infection, but are lower in magnitude. Protective immunity is correlated with levels of neutralizing $\mathrm{Ab}$, but the actual immunologic determinants of protection are not known. Because measles is highly transmissible, control requires high levels of population immunity. Delivery of the two doses of vaccine needed to achieve $>90 \%$ immunity is accomplished by routine immunization of infants at 9-15 months of age followed by a second dose delivered before school entry or by periodic mass vaccination campaigns. Because delivery by injection creates hurdles to sustained high coverage, there are efforts to deliver $\mathrm{MeV}$ vaccine by inhalation. In addition, the safety record for the vaccine combined with advances in reverse genetics for negative strand viruses has expanded proposed uses for recombinant versions of measles vaccine as vectors for immunization against other infections and as oncolytic agents for a variety of tumors.
\end{abstract}

Keywords: measles, attenuation, population immunity

\section{Introduction}

$\mathbf{M}$ EASLES IS A HIGHLY CONTAGIOUS systemic viral disease that remains one of the most important causes of worldwide morbidity and mortality in children despite the availability of a safe and efficacious vaccine $(96,107,130$, 166,185). Wild-type (WT) measles virus (MeV) is transmitted by aerosol or respiratory droplet $(77,90)$ and spreads from the respiratory tract to lymphoid tissue with giant cell formation in germinal centers, the thymus, and submucosal sites (115). Infected mononuclear cells enter the circulation and spread the virus to multiple nonlymphoid organs (e.g., skin, conjunctivae, kidney, lung, and liver) where it replicates primarily in endothelial cells, epithelial cells, and macrophages $(40,41,95,170)$. During this 10-14-day period of virus replication and systemic spread, type 1 interferon (IFN) is not induced and the infection is clinically silent. The onset of fever and rash after about 2 weeks are manifestations of the $\mathrm{MeV}$-specific cellular immune response (97) and coincide with the process of infectious virus clearance. However, clearance of viral RNA from blood and infected tissues is slow and occurs over weeks to months after resolution of the rash $(53,79,129,146)$. Complications that can result in death or long-term disability include immunosuppression with a prolonged increase in susceptibility to other infections (93), immune dysregulation with autoimmune encephalomyelitis $(62,92)$, and virus persistence in the nervous system with late development of subacute sclerosing panencephalitis $(156,184)$. Recovery is associated with life-long protective immunity.

$\mathrm{MeV}$, the causative agent of measles, is a negative-sense RNA virus with a nonsegmented genome and a lipid envelope that belongs to the morbillivirus genus of the family Paramyxoviridae. The $16 \mathrm{~kb}$ genome encodes eight proteins. Six proteins are found in the virion. The envelope has surface projections composed of the viral hemagglutinin $(\mathrm{H})$ and fusion $(\mathrm{F})$ glycoproteins. $\mathrm{H}$ interacts with the virus receptor on susceptible cells for attachment and F interacts with $\mathrm{H}$ and with the cell membrane for fusion and entry. $\mathrm{F}$ is produced as a precursor $\mathrm{F}_{0}$ that must be processed by 
cellular proteases to the disulfide-linked $\mathrm{F}_{1}-\mathrm{F}_{2}$ fusion-active form for virions to be infectious. The helical ribonucleocapsid is formed from the genomic RNA wrapped by the nucleocapsid $(\mathrm{N})$ protein with the phosphoprotein $(\mathrm{P})$ and large polymerase (L) proteins attached. The matrix (M) protein interacts with the ribonucleocapsid and glycoprotein tails for virion assembly. $\mathrm{C}$ and $\mathrm{V}$ are nonstructural proteins encoded within the $\mathrm{P}$ gene that regulate the cell response to infection and modulate IFN signaling $(10,21)$. The $\mathrm{V}$ protein interferes with activation of RNA helicase MDA5 by preventing PP1-mediated dephosphorylation of the CARD domain and $\mathrm{I} \kappa \mathrm{B}$ kinase $\alpha$ to interfere with IFN induction $(27,126,132)$ and with Stat $1 / 2$ to inhibit IFN signaling $(19,140)$. The C protein downregulates viral RNA synthesis and production of defective interfering (DI) RNAs to decrease virus detection intracellularly $(59,106,121,133)$. MeV is an antigenically monotypic virus, with 24 genotypes recognized based on the sequence of the $\mathrm{C}$ terminus of the $\mathrm{N}$ gene (148).

$\mathrm{MeV}$ targets several types of cells (e.g., B and T lymphocytes, monocytes, and endothelial and epithelial cells) and uses multiple receptors in a virus strain and cell typespecific manner determined by the $\mathrm{H}$ protein. Three receptors have been identified: membrane cofactor protein or CD46, a complement regulatory protein present on all nucleated cells $(35,109)$; signaling lymphocytic activation molecule (SLAM) or CD150, present on activated immune cells (177); and polio virus receptor related 4 or nectin 4 , present on epithelial cells $(101,114,158)$. The binding sites for these cellular receptors are overlapping on the lateral surface of the $\beta$-propeller head structure of $\mathrm{H}$ at sites targeted by neutralizing antibody $(\mathrm{Ab})(57,154)$. $\mathrm{MeV}$ probably uses additional receptors for infection of endothelial cells (40) and cells of the central nervous system $(91,162) . \mathrm{H}$ interactions with cellular receptors promote virus entry by activating $\mathrm{F}_{1}-\mathrm{F}_{2}$ trimers and triggering $\mathrm{pH}$-independent fusion of the virus envelope with the cell plasma membrane (134-136), but other modes of entry may be important in primary cells (46).

\section{Vaccine Development History}

Enders and Peebles isolated $\mathrm{MeV}$ in tissue culture by inoculating primary human kidney cells with the blood of David Edmonston, a child with measles (38). Two vaccines were developed and licensed: a formalin-inactivated whole virus vaccine and a live attenuated vaccine.

\section{Inactivated vaccine}

The formalin-inactivated measles vaccine was delivered with a three-dose schedule, but provided only short-term protection from measles and primed for a more severe disease, atypical measles. Previously vaccinated children exposed to and infected with WT MeV were at risk for developing a prolonged high fever, hemorrhagic or vesicular rash, and severe pneumonitis (142). Studies in monkeys have shown that atypical measles is due to failure of the inactivated vaccine to induce a mature $\mathrm{Ab}$ or $\mathrm{T}$ cell response with production of low avidity Ab that does not effectively neutralize WT virus. After WT MeV infection, large amounts of low avidity Abs are produced that bind, but do not neutralize, $\mathrm{MeV}$, leading to immune complex formation, vasculitis, and pneumonitis $(137,138)$. Experience with the inactivated $\mathrm{MeV}$ vaccine emphasized the potential for vaccine-induced enhancement of disease and was withdrawn.

\section{Live attenuated vaccine}

The live attenuated measles vaccine was developed at the same time as the formalin-inactivated vaccine with initial passage of the Edmonston virus in primary renal and amnion cells (Fig. 1). Subsequent passage in chick embryo fibroblasts (CEFs) produced the Edmonston $\mathrm{A}$ and $\mathrm{B}$ viruses that no longer produced disease in macaques (65). The Edmonston B vaccine was licensed in 1963, but frequently produced fever and rash (64,73). Further virus passage in CEFs yielded the more attenuated viruses Moraten (Attenuvax) and Schwarz that induce fever and rash in $<10 \%$ of those vaccinated $(147,157)$. Edmonston-Zagreb (EZ) has a slightly different lineage that includes passage in human WI-38 cells $(8,128)$ and is the vaccine strain most widely used in resource-poor countries. Vaccine virus strains, including independently developed CAM-70, Leningrad-16, and Shanghai-191, are all closely related genotype A viruses with few sequence differences $(8,127,147)$.

\section{Molecular Determinants of Attenuation}

The original Edmonston strain of $\mathrm{MeV}$ is not available and genotype A viruses are extinct (148), so it is not possible to directly compare attenuated vaccine viruses with the original WT virus from which they were derived. Although the earliest available passaged virus (Edmonston "WT") does not cause a rash in macaques, it does produce a viremia $(5,181)$. During adaptation of WT Edmonston to growth in CEFs (67), the virus was attenuated, but continued to replicate well enough to induce an immune response that protected monkeys from experimental infection and children from acquiring measles $(37,66)$. Moraten, Schwarz, and EZ vaccine strains are in widespread use today. Moraten and Schwarz are identical in sequence and EZ differs from Moraten/Schwarz at 21 amino acids $(8,127,128)$. Sequences of vaccine strains compared with current WT strains reveal differences in most viral proteins, any of which may contribute to attenuation and no one change or combination of changes has been identified as responsible for attenuation $(6,8,36,63,105,127,128,173-175)$.

Because adaptation of WT MeV to growth in Vero cells selects for a virus that no longer causes a rash in monkeys $(6,70,175)$, many studies of virulence have focused on the changes required for growth of $\mathrm{WT} \mathrm{MeV} \mathrm{in} \mathrm{Vero} \mathrm{cells} \mathrm{or}$ CEFs. Changes in multiple protein genes (P/C/V, M, F, H, and L) are selected $(7,36,60,94,160,168,169,172,173,178,186)$. Construction of recombinant viruses using the Japanese IC-B WT and CAM-70 vaccine strains has shown that changes in $\mathrm{M}, \mathrm{F}, \mathrm{H}$, and $\mathrm{L}$ all contribute to efficient growth of CAM-70 in CEFs $(63,160)$, but which one or combination of changes alters in vivo virulence has not been identified.

\section{Potential importance of $\mathrm{H}$}

One potentially important biologic difference is the acquisition of efficient use of the CD46 receptor by vaccine strains $(17,39,187)$. Tyr at position 481 of $\mathrm{H}$ (present in all vaccine strains) and Gly at 546 (present in Moraten, but not in EZ) are 


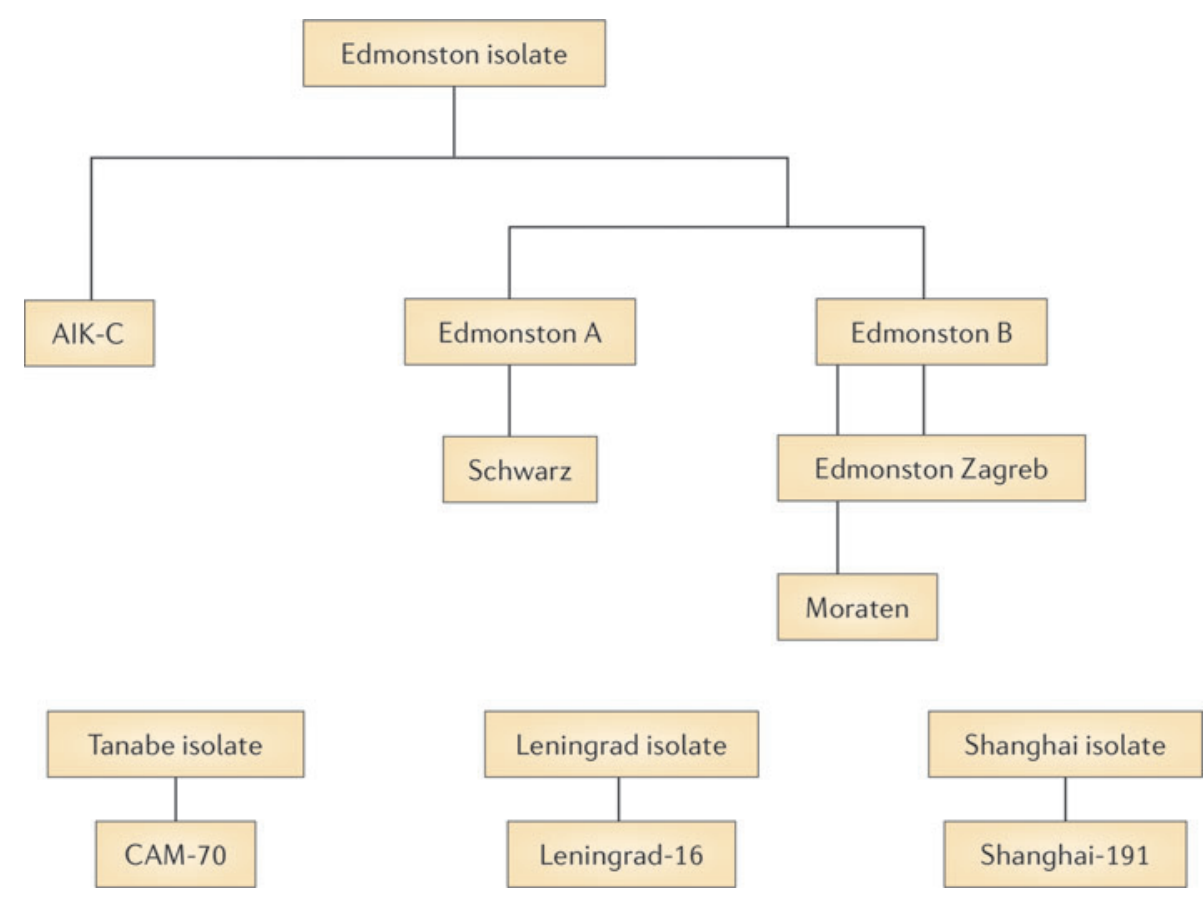

FIG. 1. Development of the live attenuated measles virus vaccine. The original Edmonston wild type virus was isolated in human cells and attenuated primarily by passage in chick embryo fibroblasts. Edmonston B was the first licensed vaccine, but fever and rash were frequent complications. The further attenuated Schwarz, Moraten, and Edmonston-Zagreb vaccine strains are widely used throughout the world. From Moss and Griffin (96) with permission of the publisher.

key determinants of the affinity of $\mathrm{H}$ for CD46 $(9,161)$, but other residues also contribute to this interaction $(88,147$, 155,168). The mechanism by which gaining use of the CD46 receptor might lead to vaccine attenuation is not clear, unless the important consequence is loss of another interaction such as $\mathrm{H}$ binding to toll-like receptor (TLR) 2 (12).

SLAM is expressed on immature thymocytes, activated lymphocytes, activated monocytes, and mature dendritic cells (DCs) $(20,32)$ and is the most important receptor for $\mathrm{MeV}$ infection of lymphoid tissue $(28,75)$. H residues important for binding SLAM are generally shared between $\mathrm{MeV}$ strains, and both vaccine and WT viruses use SLAM as a receptor $(39,86-88,111,119,153,155,182,187)$. Evaluation in cynomolgus macaques of recombinant enhanced green fluorescent protein (eGFP)-expressing WT viruses with vaccine (Ed-tag) $\mathrm{H}$ instead of WT (IC-B) H showed attenuation without a change in tropism, suggesting that the important effect is on replication rather than on receptor binding (176). Viruses with WT Asn at H481 interact with SLAM, but not CD46, activate TLR2, and enter peripheral blood mononuclear cells (PBMCs) more efficiently than viruses with Tyr (confers CD46 binding) at this position $(12,39,155)$, but the importance of changes in any of these parameters for in vivo attenuation is unclear.

\section{Potential importance of $C$ and $V$}

Differences in induction of IFN have been proposed to explain the differences between WT (good blocking of IFN induction) and vaccine (poor blocking of IFN induction) strains of $\mathrm{MeV}$ in ability to cause disease (118). Multiple in vitro studies have compared type I IFN induction by vaccine and WT strains $(110,132,163)$ of $\mathrm{MeV}$. Some studies have shown more efficient induction of IFN by vaccine $\mathrm{MeV}$, whereas others have not. However, interpretation has been complicated by use of vaccine virus stocks that contain viral particles with DI RNAs that efficiently induce IFN and are produced during $\mathrm{MeV}$ replication in tissue culture $(68,163,165)$. The $\mathrm{C}$ and $\mathrm{V}$ sequences of vaccine and WT $\mathrm{MeV}$ strains are similar (44), but the literature on sequencedependent effects on function has been complicated by the analysis of recombinant viruses that contain mutations (Y110H, C272R) present in the early MeV vaccine cDNA clone (EdTag) used for reverse genetics that are not present in vaccine strains $(33,159,171)$. Analysis of validated $\mathrm{C}$ and $\mathrm{V}$ proteins from vaccine and WT strains shows no differences in ability to regulate the IFN response $(44,105)$.

There is little evidence of type I IFN induction in humans with measles (190), but this has been difficult to study because infection is not recognized until after the adaptive immune response (rash) appears $\sim 2$ weeks after infection. Therefore, tissues from macaques infected with vaccine and WT strains of $\mathrm{MeV}$ were analyzed from the time of infection using quantitative reverse transcriptase (RT)-polymerase chain reaction to assess levels of IFN and IFN-stimulated gene (ISG) mRNAs and a flow cytometry-based bioassay to assess levels of biologically active IFN both early and late after infection. These studies showed little to no induction of type I IFN, type III IFN, Mx, or ISG56 mRNAs in monkeys infected with vaccine or WT MeV and no IFN was detected by bioassay (164). Therefore, there is no evidence that the $\mathrm{MeV} \mathrm{P} / \mathrm{C} / \mathrm{V}$ protein gene is a determinant of vaccine attenuation.

\section{Biologic Determinants of Attenuation}

The in vivo target cells for vaccine strains of $\mathrm{MeV}$ are not well characterized, but replication is restricted compared with WT MeV despite an enhanced ability to use widely 
distributed CD46, as well as SLAM, as a receptor. Limited in vivo studies suggest that vaccine and WT viruses replicate equally well in the respiratory tract, but that vaccine virus replicates less well in lymphoid tissue resulting in lower levels of virus in circulating PBMCs (viremia), potentially accounting both for less serious disease and a less vigorous immune response to infection $(5,78,181)$. DCs and tissue macrophages are major early myeloid cell targets of WT and vaccine $\mathrm{MeV}(28,30)$, and after intramuscular infection of macaques with eGFP-expressing EZ MeV vaccine, infected DCs and macrophages can be visualized at the site of inoculation (144).

During systemic spread of WT MeV, vascular endothelial cells and epithelial cells in multiple organs become infected $(40,95)$. Endothelial cells express CD46 (91) but not SLAM (3), can be induced to express nectin 4 (1), and infection may provide an important pathway for entry into many tissues. In vitro studies of human microvascular and umbilical vein endothelial cells have shown that vaccine strains infect endothelial cells more efficiently and replicate virus better than WT MeV $(1,3)$. Likewise, monocyte-derived DCs replicate vaccine $\mathrm{MeV}$ better than WT MeV, do not produce types I or III IFN in response to infection, and develop very limited upregulation of ISGs (165).

In vitro studies of primary human myeloid and lymphoid cells and thymus and tonsil explants tend to show that $\mathrm{MeV}$ strains initiate infection similarly in cells, but that less infectious virus is produced by vaccine than WT strains $(4,26$, $30,55,117,165,180)$. $\mathrm{CD} 4^{+} \mathrm{CD}^{+}$double-positive thymocytes are susceptible to infection with vaccine and WT MeV, but vaccine strains infect less efficiently (require higher multiplicities of infection) and take longer to produce virus than WT strains (117).

\section{Vaccine-Induced Protective Immunity}

The live attenuated $\mathrm{MeV}$ vaccine induces both $\mathrm{Ab}$ and cellular immune responses that mature over months $(78,104)$. The vaccine protects against infection with all genotypes of $\mathrm{MeV}$ (8). Protection correlates best with the quality and quantity of neutralizing $\mathrm{Ab}$ induced $(23,139)$ but $\mathrm{T}$ cells likely contribute (152). Ab that neutralizes infectivity of $\mathrm{MeV}$ is directed primarily against the $\mathrm{H}$ protein, with some contribution from $\mathrm{Ab}$ to $\mathrm{F}(29)$. $\mathrm{H}$ also contains important $\mathrm{CD}^{+}$ $\mathrm{T}$ cell epitopes (121). High avidity $\mathrm{Ab}$ to $\mathrm{H}$ is required for neutralization of SLAM-mediated WT MeV infection of lymphoid cells, but not for neutralization of CD46-mediated vaccine virus infection of Vero cells commonly used for measuring levels of $\mathrm{MeV}$ neutralizing $\mathrm{Ab}$ (138). Studies in macaques have shown that neutralizing Ab predicts protection from disease (rash), but not necessarily from infection, and that $\mathrm{T}$ cells alone do not protect from either infection or disease, but do facilitate clearance of viral RNA $(80,122-$ 125).

Although vaccine-induced immune responses are qualitatively similar to those induced by infection with WT MeV, levels of Abs, particularly $\mathrm{H}$-specific neutralizing Abs, are lower after vaccination (116). Young age affects the quality and quantity of infant $\mathrm{Ab}$ responses, but has less of an effect on $\mathrm{T}$ cell responses $(48,49,103,143)$. Increasing the dose of vaccine $\sim 100$-fold (from $10^{3}$ to $10^{5} \mathrm{pfu}$ ) improved the $\mathrm{Ab}$ responses in young infants, but resulted in an unexpected increase in mortality for girls $(50,58,61,69)$, so this WHO recommendation was withdrawn. With time, $\mathrm{MeV}$-specific Abs and $\mathrm{CD}^{+} \mathrm{T}$ cells induced by vaccine decrease $(22,24,71,108)$, and secondary vaccine failure rates are estimated to be $\sim 5 \% 10-15$ years after immunization $(2,89)$. Lack of a sustained protective response is a particular problem in HIV-infected children $(45,98,104,112)$. Attempts to boost immunity with repeated immunization have generally led to only transient improvements in either levels of neutralizing $\mathrm{Ab}$ or $\mathrm{MeV}$-specific $\mathrm{T}$ cell responses (42) and raise the possibility that new vaccine approaches may be required for measles control in the future (54).

\section{Vaccine Delivery and Control of Measles Transmission}

In industrialized countries, the current vaccine is usually given subcutaneously or intramuscularly in combination with live virus vaccines for mumps, rubella (MMR), and sometimes varicella (MMRV). In resource-poor countries, $\mathrm{MeV}$ vaccine is often given alone, but there is an effort for these countries to transition to delivery of combined measles and rubella (MR) vaccine (72).

Not all children respond to the initial dose of $\mathrm{MeV}$ containing vaccine given in infancy (85\% at 9 months, $95 \%$ at 12 months) (179), so two doses are required to provide a second opportunity for response and achieve a population immunity of $92-95 \%$ required to eliminate endemic transmission (51). With institution of mass campaigns to deliver the second dose in developing countries, strides have been made toward global measles control, but logistical and financial difficulties have slowed progress with recent increases in measles cases and deaths in many countries $(97,130,166)$. In addition, complacency, concerns about safety, and philosophical and religious objections to vaccination have resulted in a resurgence of measles in many industrialized nations $(43,102,130,145,151)$. Delivery by inhalation rather than needle and syringe has been proposed to help improve coverage $(56,84,120)$, and both aerosol and dry powder versions of the EZ vaccine are in development for use both for use in primary immunization of infants and for delivery of the second dose to older children $(18,34,52,56,76$, $78,84,150)$.

\section{Expanded Uses of MeV Vaccine}

\section{Vaccines against other infectious diseases}

Efficient systems have been developed for production of recombinant MeVs $(25,131,144)$ and these techniques are being applied to develop $\mathrm{MeV}$ vaccine as a vector for immunization against other virus infections $(82,100)$ : for example, dengue $(13,15,16)$, West Nile (31), HIV $(83,167)$, MERS (85), and chikungunya (CHIKV) (14). A phase 1 trial of the $\mathrm{MeV}$ recombinant CHIKV vaccine showed that it was safe and induced Abs to CHIKV in adults with pre-existing MeV immunity (141).

\section{Cancer treatment}

Because the $\mathrm{MeV}$ vaccine is cytolytic for many tumor cells in vitro $(11,113)$, recombinant $\mathrm{MeVs}$ are also being retargeted as oncolytic agents for cancer therapy. These approaches have shown promise in animal models and clinical trials using 
doses orders of magnitude higher than those required for vaccination and have been initiated for treatment of multiple myeloma, ovarian cancer, T cell lymphoma, and glioblastoma $(47,74,81,99,149,183,188,189)$.

These new uses for $\mathrm{MeV}$ vaccine are likely to continue to expand and increase the need for a better understanding of the mechanisms of attenuation, sites of replication, and immunogenicity of $\mathrm{MeV}$ vaccine.

\section{Summary}

The live attenuated $\mathrm{MeV}$ vaccine in current use is safe and effective and has saved millions of lives. The vaccine induces $\mathrm{Ab}$ and $\mathrm{T}$ cell-mediated immunity that is durable, but not readily boosted. Despite long use, neither the determinants of attenuation nor of protective immunity have been identified and deserve investigation. The reasons for failures of the formalin-inactivated vaccine and the high titer live virus vaccine are only partially understood and provide cautionary tales for development of other vaccines. Success of the current vaccine has led to expanded development as a platform for other vaccines and as an oncolytic agent.

\section{Acknowledgments}

Work from the author's laboratory was supported by research grants from the National Institutes of Health (R01 AI023047, R21 AI095981, and T32 AI007417) and by the Bill and Melinda Gates Foundation. The contributions of many members of the laboratory who have helped with these studies are gratefully acknowledged.

\section{Author Disclosure Statement}

No competing financial interests exist.

\section{References}

1. Abdullah H, Brankin B, Brady C, et al. Wild-type measles virus infection upregulates poliovirus receptor-related 4 and causes apoptosis in brain endothelial cells by induction of tumor necrosis factor-related apoptosis-inducing ligand. J Neuropathol Exp Neurol 2013;72:681-696.

2. Anders JF, Jacobson RM, Poland GA, et al. Secondary failure rates of measles vaccines: a metaanalysis of published studies. Pediatr Infect Dis J 1996;15:62-66.

3. Andres O, Obojes K, Kim KS, et al. CD46- and CD150independent endothelial cell infection with wild-type measles viruses. J Gen Virol 2003;84:1189-1197.

4. Auwaerter PG, Kaneshima H, McCune JM, et al. Measles virus infection of thymic epithelium in the SCID-hu mouse leads to thymocyte apoptosis. J Virol 1996;70: 3734-3740.

5. Auwaerter PG, Rota PA, Elkins WR, et al. Measles virus infection in rhesus macaques: altered immune responses and comparison of the virulence of six different virus strains. J Infect Dis 1999;180:950-958.

6. Bankamp B, Hodge G, McChesney MB, et al. Genetic changes that affect the virulence of measles virus in a rhesus macaque model. Virology 2008;373:39-50.

7. Bankamp B, Lopareva EN, Kremer JR, et al. Genetic variability and mRNA editing frequencies of the phosphoprotein genes of wild-type measles viruses. Virus Res 2008;135:298-306.
8. Bankamp B, Takeda M, Zhang Y, et al. Genetic characterization of measles vaccine strains. J Infect Dis 2011; 204 Suppl 1:S533-S548.

9. Bartz R, Brinckmann U, Dunster LM, et al. Mapping amino acids of the measles virus hemagglutinin responsible for receptor (CD46) downregulation. Virology 1996; 224:334-337.

10. Bellini WJ, Englund G, Rozenblatt S, et al. Measles virus P gene codes for two proteins. J Virol 1985;53:908-919.

11. Berchtold S, Lampe J, Weiland T, et al. Innate immune defense defines susceptibility of sarcoma cells to measles vaccine virus-based oncolysis. J Virol 2013;87:3484-3501.

12. Bieback K, Lien E, Klagge IM, et al. Hemagglutinin protein of wild-type measles virus activates toll-like receptor 2 signaling. J Virol 2002;76:8729-8736.

13. Brandler S, Lucas-Hourani M, Moris A, et al. Pediatric measles vaccine expressing a dengue antigen induces durable serotype-specific neutralizing antibodies to dengue virus. PLoS Negl Trop Dis 2007;1:e96.

14. Brandler S, Ruffie C, Combredet C, et al. A recombinant measles vaccine expressing chikungunya virus-like particles is strongly immunogenic and protects mice from lethal challenge with chikungunya virus. Vaccine 2013;31: 3718-3725.

15. Brandler S, Ruffie C, Najburg V, et al. Pediatric measles vaccine expressing a dengue tetravalent antigen elicits neutralizing antibodies against all four dengue viruses. Vaccine 2010;28:6730-6739.

16. Brandler S, and Tangy F. Recombinant vector derived from live attenuated measles virus: potential for flavivirus vaccines. Comp Immunol Microbiol Infect Dis 2008;31: 271-291.

17. Buckland R, and Wild TF. Is CD46 the cellular receptor for measles virus? Virus Res 1997;48:1-9.

18. Burger JL, Cape SP, Braun CS, et al. Stabilizing formulations for inhalable powders of live-attenuated measles virus vaccine. J Aerosol Med Pulm Drug Deliv 2008;21: 25-34.

19. Caignard G, Guerbois M, Labernardiere JL, et al. Measles virus $\mathrm{V}$ protein blocks Jak1-mediated phosphorylation of STAT1 to escape IFN-alpha/beta signaling. Virology 2007;368:351-362.

20. Cannons JL, Tangye SG, and Schwartzberg PL. SLAM family receptors and SAP adaptors in immunity. Annu Rev Immunol 2011;29:665-705.

21. Cattaneo R, Kaelin K, Baczko K, et al. Measles virus editing provides an additional cysteine-rich protein. Cell 1989;56:759-764.

22. Chen CJ, Lee PI, Hsieh YC, et al. Waning population immunity to measles in Taiwan. Vaccine 2012;30:67216727.

23. Chen RT, Markowitz LE, Albrecht P, et al. Measles antibody: reevaluation of protective titers. J Infect Dis 1990; 162:1036-1042.

24. Christenson B, and Bottiger M. Measles antibody: comparison of long-term vaccination titres, early vaccination titres and naturally acquired immunity to and booster effects on the measles virus. Vaccine 1994;12:129-133.

25. Combredet C, Labrousse V, Mollet L, et al. A molecularly cloned Schwarz strain of measles virus vaccine induces strong immune responses in macaques and transgenic mice. J Virol 2003;77:11546-11554.

26. Condack C, Grivel JC, Devaux P, et al. Measles virus vaccine attenuation: suboptimal infection of lymphatic 
tissue and tropism alteration. J Infect Dis 2007;196:541549.

27. Davis ME, Wang MK, Rennick LJ, et al. Antagonism of the phosphatase PP1 by the measles virus $\mathrm{V}$ protein is required for innate immune escape of MDA5. Cell Host Microbe 2014;16:19-30.

28. de Swart RL, Ludlow M, de Witte L, et al. Predominant infection of CD150+ lymphocytes and dendritic cells during measles virus infection of macaques. PLoS Pathog 2007;3:e178.

29. de Swart RL, Yuksel S, and Osterhaus AD. Relative contributions of measles virus hemagglutinin- and fusion protein-specific serum antibodies to virus neutralization. $\mathbf{J}$ Virol 2005;79:11547-11551.

30. de Vries RD, Lemon K, Ludlow M, et al. In vivo tropism of attenuated and pathogenic measles virus expressing green fluorescent protein in macaques. J Virol 2010;84: 4714-4724.

31. Despres P, Combredet C, Frenkiel MP, et al. Live measles vaccine expressing the secreted form of the West Nile virus envelope glycoprotein protects against West Nile virus encephalitis. J Infect Dis 2005;191:207-214.

32. Detre C, Keszei M, Romero X, et al. SLAM family receptors and the SLAM-associated protein (SAP) modulate T cell functions. Semin Immunopathol 2010;32:157-171.

33. Devaux $\mathrm{P}$, von Messling $\mathrm{V}$, Songsungthong $\mathrm{W}$, et al. Tyrosine 110 in the measles virus phosphoprotein is required to block STAT1 phosphorylation. Virology 2007; 360:72-83.

34. Dilraj A, Cutts FT, de Castro JF, et al. Response to different measles vaccine strains given by aerosol and subcutaneous routes to schoolchildren: a randomised trial. Lancet 2000;355:798-803.

35. Dorig RE, Marcil A, Chopra A, et al. The human CD46 molecule is a receptor for measles virus (Edmonston strain). Cell 1993;75:295-305.

36. Druelle J, Sellin CI, Waku-Kouomou D, et al. Wild type measles virus attenuation independent of type I IFN. Virol J 2008;5:22.

37. Enders JF, Katz SL, and Holloway A. Development of attenuated measles-virus vaccines. A summary of recentinvestigation. Am J Dis Child 1962;103:335-340.

38. Enders JF, and Peebles TC. Propagation in tissue cultures of cytopathogenic agents from patients with measles. Proc Soc Exp Biol Med 1954;86:277-286.

39. Erlenhofer C, Duprex WP, Rima BK, et al. Analysis of receptor (CD46, CD150) usage by measles virus. J Gen Virol 2002;83:1431-1436.

40. Esolen LM, Takahashi K, Johnson RT, et al. Brain endothelial cell infection in children with acute fatal measles. J Clin Invest 1995;96:2478-2481.

41. Esolen LM, Ward BJ, Moench TR, et al. Infection of monocytes during measles. J Infect Dis 1993;168:47-52.

42. Fiebelkorn AP, Coleman LA, Belongia EA, et al. Measles virus neutralizing antibody response, cell-mediated immunity, and immunoglobulin $\mathrm{G}$ antibody avidity before and after receipt of a third dose of measles, mumps, and rubella vaccine in young adults. J Infect Dis 2016;213: 1115-1123.

43. Fiebelkorn AP, Redd SB, Gastanaduy PA, et al. A comparison of postelimination measles epidemiology in the United States, 2009-2014 versus 2001-2008. J Pediatr Infect Dis Soc 2015;6:40-48.
44. Fontana JM, Bankamp B, Bellini WJ, et al. Regulation of interferon signaling by the $\mathrm{C}$ and $\mathrm{V}$ proteins from attenuated and wild-type strains of measles virus. Virology 2008;374:71-81.

45. Fowlkes A, Witte D, Beeler J, et al. Persistence of vaccine-induced measles antibody beyond age 12 months: a comparison of response to one and two doses of Edmonston-Zagreb measles vaccine among HIV-infected and uninfected children in Malawi. J Infect Dis 2011;204 Suppl 1:S149-S157.

46. Frecha C, Levy C, Costa C, et al. Measles virus glycoprotein-pseudotyped lentiviral vector-mediated gene transfer into quiescent lymphocytes requires binding to both SLAM and CD46 entry receptors. J Virol 2011;85: 5975-5985.

47. Galanis E, Atherton PJ, Maurer MJ, et al. Oncolytic measles virus expressing the sodium iodide symporter to treat drug-resistant ovarian cancer. Cancer Res 2015;75: 22-30.

48. Gans HA, Arvin AM, Galinus J, et al. Deficiency of the humoral immune response to measles vaccine in infants immunized at age 6 months. JAMA 1998;280:527-532.

49. Gans HA, Yasukawa LL, Alderson A, et al. Humoral and cell-mediated immune responses to an early 2-dose measles vaccination regimen in the United States. J Infect Dis 2004;190:83-90.

50. Garenne M, Leroy O, Beau JP, et al. Child mortality after high-titre measles vaccines: prospective study in Senegal. Lancet 1991;338:903-907.

51. Gay N. The theory of measles elimination: implications for the design of elimination strategies. J Infect Dis 2004; 189:S27-S35.

52. Griffin DE. Current progress in pulmonary delivery of measles vaccine. Expert Rev Vaccines 2014;13:751-759.

53. Griffin DE, Lin WH, and Pan CH. Measles virus, immune control, and persistence. FEMS Microbiol Rev 2012;36: 649-662.

54. Griffin DE, and Pan CH. Measles: old vaccines, new vaccines. Curr Topics Microbiol Immunol 2009;330:191212.

55. Grivel JC, Garcia M, Moss WJ, et al. Inhibition of HIV-1 replication in human lymphoid tissues ex vivo by measles virus. J Infect Dis 2005;192:71-78.

56. Group Ma, Cape S, Chaudhari A, et al. Safety and immunogenicity of dry powder measles vaccine administered by inhalation: a randomized controlled phase I clinical trial. Vaccine 2014;32:6791-6797.

57. Hashiguchi T, Ose T, Kubota M, et al. Structure of the measles virus hemagglutinin bound to its cellular receptor SLAM. Nature Struct Mol Biol 2011;18:135-141.

58. Holt EA, Moulton LH, Siberry GK, et al. Differential mortality by measles vaccine titer and sex. J Infect Dis 1993;168:1087-1096.

59. Ito M, Iwasaki M, Takeda M, et al. Measles virus nonstructural $\mathrm{C}$ protein modulates viral RNA polymerase activity by interacting with host protein SHCBP1. J Virol 2013;87:9633-9642.

60. Iwasaki M, Takeda M, Shirogane Y, et al. The matrix protein of measles virus regulates viral RNA synthesis and assembly by interacting with the nucleocapsid protein. $\mathrm{J}$ Virol 2009;83:10374-10383.

61. Job JS, Halsey NA, Boulos R, et al. Successful immunization of infants at 6 months of age with high dose 
Edmonston-Zagreb measles vaccine. Cite Soleil/JHU Project Team. Pediatr Infect Dis J 1991;10:303-311.

62. Johnson RT, Griffin DE, Hirsch RL, et al. Measles encephalomyelitis-clinical and immunologic studies. N Engl J Med 1984;310:137-141.

63. Kato S, Ohgimoto S, Sharma LB, et al. Reduced ability of hemagglutinin of the CAM-70 measles virus vaccine strain to use receptors CD46 and SLAM. Vaccine 2009; 27:3838-3848.

64. Katz SL, Enders JF, and Holloway A. Studies on an attenuated measles-virus vaccine. II. Clinical, virologic and immunologic effects of vaccine in institutionalized children. N Engl J Med 1960;263:159-161.

65. Katz SL, Enders JF, and Holloway A. The development and evaluation of an attenuated measles virus vaccine. Am J Public Health Nations Health 1962;52Suppl:5-10.

66. Katz SL, Kempe CH, Black FL, et al. Studies on an attenuated measles-virus vaccine. VIII. General summary and evaluation of the results of vaccination. Am J Dis Child 1960;100:942-946.

67. Katz SL, Milovanovic MV, and Enders JF. Propagation of measles virus in cultures of chick embryo cells. Proc Soc Exp Biol Med 1958;97:23-29.

68. Kessler JR, Kremer JR, and Muller CP. Interplay of measles virus with early induced cytokines reveals different wild type phenotypes. Virus Res 2011;155:195-202.

69. Knudsen KM, Aaby P, Whittle H, et al. Child mortality following standard, medium or high titre measles immunization in West Africa. Int J Epidemiol 1996;25: 665-673.

70. Kobune F, Sakata H, and Sugiura A. Marmoset lymphoblastoid cells as a sensitive host for isolation of measles virus. J Virol 1990;64:700-705.

71. Kontio M, Jokinen S, Paunio M, et al. Waning antibody levels and avidity: implications for MMR vaccine-induced protection. J Infect Dis 2012;206:1542-1548.

72. Kretsinger K, Strebel P, Kezaala R, et al. Transitioning lessons learned and assets of the global polio eradication initiative to global and regional measles and rubella elimination. J Infect Dis 2017;216:S308-S315.

73. Krugman S, Muriel G, and Fontana VJ. Combined live measles, mumps, rubella vaccine. Immunological response. Am J Dis Child 1971;121:380-381.

74. Lech PJ, and Russell SJ. Use of attenuated paramyxoviruses for cancer therapy. Expert Rev Vaccines 2010;9:1275-1302.

75. Leonard VH, Hodge G, Reyes-Del Valle J, et al. Measles virus selectively blind to signaling lymphocytic activation molecule (SLAM; CD150) is attenuated and induces strong adaptive immune responses in rhesus monkeys. J Virol 2010;84:3413-3420.

76. LiCalsi C, Maniaci MJ, Christensen T, Phillips E, Ward $\mathrm{GH}$, and Witham C. A powder formulation of measles vaccine for aerosol delivery. Vaccine 2001;19:2629-2636.

77. Lightwood R, and Nolan R. Epithelial giant cells in measles as an acid in diagnosis. J Pediatr 1970;77:59-64.

78. Lin WH, Griffin DE, Rota PA, et al. Successful respiratory immunization with dry powder live-attenuated measles virus vaccine in rhesus macaques. Proc Natl Acad Sci U S A 2011;108:2987-2992.

79. Lin WH, Kouyos RD, Adams RJ, et al. Prolonged persistence of measles virus RNA is characteristic of primary infection dynamics. Proc Natl Acad Sci U S A 2012;109: 14989-14994.
80. Lin WH, Pan $\mathrm{CH}$, Adams RJ, et al. Vaccine-induced measles virus-specific $\mathrm{T}$ cells do not prevent infection or disease but facilitate subsequent clearance of viral RNA. MBio 2014;5:e01047.

81. Liu YP, Steele MB, Suksanpaisan L, et al. Oncolytic measles and vesicular stomatitis virotherapy for endometrial cancer. Gynecol Oncol 2014;132:194-202.

82. Lorin C, Combredet C, Labrousse V, et al. A paediatric vaccination vector based on live attenuated measles vaccine. Therapie 2005;60:227-233.

83. Lorin C, Mollet L, Delebecque F, et al. A single injection of recombinant measles virus vaccines expressing human immunodeficiency virus (HIV) type 1 clade B envelope glycoproteins induces neutralizing antibodies and cellular immune responses to HIV. J Virol 2004;78:146-157.

84. Low N, Bavdekar A, Jeyaseelan L, et al. A randomized, controlled trial of an aerosolized vaccine against measles. New Engl J Med 2015;372:1519-1529.

85. Malczyk AH, Kupke A, Prufer S, et al. A highly immunogenic and protective Middle East respiratory syndrome coronavirus vaccine based on a recombinant measles virus vaccine platform. J Virol 2015;89:11654-11667.

86. Manchester M, Eto DS, Valsamakis A, et al. Clinical isolates of measles virus use CD46 as a cellular receptor. J Virol 2000;74:3967-3974.

87. Masse N, Ainouze M, Neel B, et al. Measles virus (MV) hemagglutinin: evidence that attachment sites for MV receptors SLAM and CD46 overlap on the globular head. J Virol 2004;78:9051-9063.

88. Masse N, Barrett T, Muller CP, et al. Identification of a second major site for CD46 binding in the hemagglutinin protein from a laboratory strain of measles virus (MV): potential consequences for wild-type $\mathrm{MV}$ infection. J Virol 2002;76:13034-13038.

89. Mathias RG, Meekison WG, Arcand TA, et al. The role of secondary vaccine failures in measles outbreaks. Am J Public Health 1989;79:475-478.

90. McChesney MB, Miller CJ, Rota PA, et al. Experimental measles. I. Pathogenesis in the normal and the immunized host. Virology 1997;233:74-84.

91. McQuaid S, and Cosby SL. An immunohistochemical study of the distribution of the measles virus receptors, CD46 and SLAM, in normal human tissues and subacute sclerosing panencephalitis. Lab Invest 2002;82:403-409.

92. Miller DL. Frequency of complications of measles, 1963. Report on a National Inquiry by the Public Health Laboratory Service in Collaboration with the Society of Medical Officers of Health. Br Med J 1964;2:75-78.

93. Mina MJ, Metcalf CJ, de Swart RL, et al. Vaccines. Longterm measles-induced immunomodulation increases overall childhood infectious disease mortality. Science 2015;348:694-699.

94. Miyajima N, Takeda M, Tashiro M, et al. Cell tropism of wild-type measles virus is affected by amino acid substitutions in the $\mathrm{P}, \mathrm{V}$ and $\mathrm{M}$ proteins, or by a truncation in the C protein. J Gen Virol 2004;85:3001-3006.

95. Moench TR, Griffin DE, Obriecht CR, et al. Acute measles in patients with and without neurological involvement: distribution of measles virus antigen and RNA. J Infect Dis 1988;158:433-442.

96. Moss WJ, and Griffin DE. Global measles elimination. Nat Rev Microbiol 2006;4:900-908.

97. Moss WJ, and Griffin DE. Measles. Lancet 2012;379:153164. 
98. Moss WJ, Scott S, Mugala N, et al. Immunogenicity of standard-titer measles vaccine in HIV-1-infected and uninfected Zambian children: an observational study. J Infect Dis 2007;196:347-355.

99. Msaouel P, Opyrchal M, Dispenzieri A, et al. Clinical trials with oncolytic measles virus: current status and future prospects. Curr Cancer Drug Targets 2017 [Epub ahead of print]; DOI: 10.2174/1568009617666170222 125035.

100. Muhlebach MD. Vaccine platform recombinant measles virus. Virus Genes 2017;53:733-740.

101. Muhlebach MD, Mateo M, Sinn PL, et al. Adherens junction protein nectin- 4 is the epithelial receptor for measles virus. Nature 2011;480:530-533.

102. Muscat M, Bang H, Wohlfahrt J, et al. Measles in Europe: an epidemiological assessment. Lancet 2009;373:383-389.

103. Nair N, Gans H, Lew-Yasukawa L, et al. Age-dependent differences in IgG isotype and avidity induced by measles vaccine received during the first year of life. J Infect Dis 2007;196:1339-1345.

104. Nair N, Moss WJ, Scott S, et al. HIV-1 infection in Zambian children impairs the development and avidity maturation of measles virus-specific immunoglobulin $\mathrm{G}$ after vaccination and infection. J Infect Dis 2009;200: 1031-1038.

105. Nakatsu Y, Takeda M, Iwasaki M, et al. A highly attenuated measles virus vaccine strain encodes a fully functional C protein. J Virol 2009;83:11996-12001.

106. Nakatsu Y, Takeda M, Ohno S, et al. Measles virus circumvents the host interferon response by different actions of the C and V proteins. J Virol 2008;82:8296-8306.

107. Nandy R, Handzel T, Zaneidou M, et al. Case-fatality rate during a measles outbreak in eastern Niger in 2003. Clin Infect Dis 2006;42:322-328.

108. Naniche D, Garenne M, Rae C, et al. Decrease in measles virus-specific CD4 T cell memory in vaccinated subjects. J Infect Dis 2004;190:1387-1395.

109. Naniche D, Wild TF, Rabourdin-Combe C, et al. Measles virus haemagglutinin induces down-regulation of gp57/67, a molecule involved in virus binding. J Gen Virol 1993;74 (Pt 6):1073-1079.

110. Naniche D, Yeh A, Eto D, et al. Evasion of host defenses by measles virus: wild-type measles virus infection interferes with induction of Alpha/Beta interferon production. J Virol 2000;74:7478-7484.

111. Navaratnarajah CK, Vongpunsawad S, Oezguen $\mathrm{N}$, et al. Dynamic interaction of the measles virus hemagglutinin with its receptor signaling lymphocytic activation molecule (SLAM, CD150). J Biol Chem 2008;283:11763-11771.

112. Newman LP, Njoroge A, Magaret A, et al. Sustained responses to measles revaccination at 24 months in HIVinfected children on antiretroviral therapy in Kenya. Pediatr Infect Dis J 2017;36:1148-1155.

113. Noll M, Berchtold S, Lampe J, et al. Primary resistance phenomena to oncolytic measles vaccine viruses. Int $\mathbf{J}$ Oncol 2013;43:103-112.

114. Noyce RS, Bondre DG, Ha MN, et al. Tumor cell marker PVRL4 (nectin 4) is an epithelial cell receptor for measles virus. PLoS Pathog 2011;7:e1002240.

115. Nozawa Y, Ono N, Abe M, et al. An immunohistochemical study of Warthin-Finkeldey cells in measles. Pathol Int 1994;44:442-447.

116. Okada H, Sato TA, Katayama A, et al. Comparative analysis of host responses related to immunosuppression between measles patients and vaccine recipients with live attenuated measles vaccines. Arch Virol 2001;146:859874.

117. Okamoto Y, Vricella LA, Moss WJ, et al. Immature CD4+CD8+ thymocytes are preferentially infected by measles virus in human thymic organ cultures. PLoS One 2012; 7:e45999.

118. Oldstone MB. Viral persistence: parameters, mechanisms and future predictions. Virology 2006;344:111-118.

119. Ono N, Tatsuo H, Hidaka Y, et al. Measles viruses on throat swabs from measles patients use signaling lymphocytic activation molecule (CDw150) but not CD46 as a cellular receptor. J Virol 2001;75:4399-4401.

120. Organization WH. Meeting of the strategic advisory group of expers on immunization, November 2012- conclusions and recommendations. Weekly Epidemiol Rec 2013;88: $1-16$.

121. Ota MO, Ndhlovu Z, Oh S, et al. Hemagglutinin protein is a primary target of the measles virus-specific HLA-A2restricted CD8 $+\mathrm{T}$ cell response during measles and after vaccination. J Infect Dis 2007;195:1799-1807.

122. Pan $\mathrm{CH}$, Greer CE, Hauer D, et al. A chimeric alphavirus replicon particle vaccine expressing the hemagglutinin and fusion proteins protects juvenile and infant rhesus macaques from measles. J Virol 2010;84:3798-3807.

123. Pan CH, Jimenez GS, Nair N, et al. Use of Vaxfectin adjuvant with DNA vaccine encoding the measles virus hemagglutinin and fusion proteins protects juvenile and infant rhesus macaques against measles virus. Clin Vaccine Immunol 2008;15:1214-1221.

124. Pan CH, Nair N, Adams RJ, et al. Dose-dependent protection against or exacerbation of disease by a polylactide glycolide microparticle-adsorbed, alphavirus-based measles virus DNA vaccine in rhesus macaques. Clin Vaccine Immunol 2008;15:697-706.

125. Pan CH, Valsamakis A, Colella $\mathrm{T}$, et al. Modulation of disease, $\mathrm{T}$ cell responses, and measles virus clearance in monkeys vaccinated with $\mathrm{H}$-encoding alphavirus replicon particles. Proc Natl Acad Sci U S A 2005;102:1158111588.

126. Parisien JP, Bamming D, Komuro A, et al. A shared interface mediates paramyxovirus interference with antiviral RNA helicases MDA5 and LGP2. J Virol 2009;83:72527260.

127. Parks CL, Lerch RA, Walpita P, et al. Analysis of the noncoding regions of measles virus strains in the Edmonston vaccine lineage. J Virol 2001;75:921-933.

128. Parks CL, Lerch RA, Walpita $\mathrm{P}$, et al. Comparison of predicted amino acid sequences of measles virus strains in the Edmonston vaccine lineage. J Virol 2001;75:910-920.

129. Permar SR, Moss WJ, Ryon JJ, et al. Prolonged measles virus shedding in human immunodeficiency virus-infected children, detected by reverse transcriptase-polymerase chain reaction. J Infect Dis 2001;183:532-538.

130. Perry RT, Murray JS, Gacic-Dobo M, et al. Progress toward regional measles elimination-worldwide, 20002014. MMWR Morb Mortal Wkly Rep 2015;64:12461251.

131. Pfaller CK, Cattaneo R, and Schnell MJ. Reverse genetics of Mononegavirales: how they work, new vaccines, and new cancer therapeutics. Virology 2015;479-480:331344.

132. Pfaller CK, and Conzelmann KK. Measles virus V protein is a decoy substrate for IkappaB kinase alpha and prevents 
Toll-like receptor 7/9-mediated interferon induction. J Virol 2008;82:12365-12373.

133. Pfaller CK, Mastorakos GM, Matchett WE, et al. Measles virus defective interfering RNAs are generated frequently and early in the absence of $\mathrm{C}$ protein and can be destabilized by adenosine deaminase acting on RNA-1-like hypermutations. J Virol 2015;89:7735-7747.

134. Plemper RK, Brindley MA, and Iorio RM. Structural and mechanistic studies of measles virus illuminate paramyxovirus entry. PLoS Pathog 2011;7:e1002058.

135. Plemper RK, Hammond AL, and Cattaneo R. Characterization of a region of the measles virus hemagglutinin sufficient for its dimerization. J Virol 2000;74:6485-6493.

136. Plemper RK, Hammond AL, Gerlier D, et al. Strength of envelope protein interaction modulates cytopathicity of measles virus. J Virol 2002;76:5051-5061.

137. Polack FP, Auwaerter PG, Lee SH, et al. Production of atypical measles in rhesus macaques: evidence for disease mediated by immune complex formation and eosinophils in the presence of fusion-inhibiting antibody. Nature Med 1999;5:629-634.

138. Polack FP, Hoffman SJ, Crujeiras G, et al. A role for nonprotective complement-fixing antibodies with low avidity for measles virus in atypical measles. Nature Med 2003;9:1209-1213.

139. Polack FP, Lee SH, Permar S, et al. Successful DNA immunization against measles: neutralizing antibody against either the hemagglutinin or fusion glycoprotein protects rhesus macaques without evidence of atypical measles. Nature Med 2000;6:776-781.

140. Ramachandran A, Parisien JP, and Horvath CM. STAT2 is a primary target for measles virus $\mathrm{V}$ protein-mediated alpha/beta interferon signaling inhibition. J Virol 2008;82: 8330-8338.

141. Ramsauer K, Schwameis M, Firbas C, et al. Immunogenicity, safety, and tolerability of a recombinant measles-virus-based chikungunya vaccine: a randomised, double-blind, placebo-controlled, active-comparator, firstin-man trial. Lancet Infect Dis 2015;15:519-527.

142. Rauh LW, and Schmidt R. Measles immunization with killed virus vaccine. Serum antibody titers and experience with exposure to measles epidemic. Am J Dis Child 1965; 109:232-237.

143. Redd SC, King GE, Heath JL, et al. Comparison of vaccination with measles-mumps-rubella vaccine at 9,12 , and 15 months of age. The J Infect Dis 2004;189 Suppl 1: S116-S122.

144. Rennick LJ, de Vries RD, Carsillo TJ, et al. Liveattenuated measles virus vaccine targets dendritic cells and macrophages in muscle of nonhuman primates. J Virol 2015;89:2192-2200.

145. Richard JL, and Masserey Spicher V. Large measles epidemic in Switzerland from 2006 to 2009: consequences for the elimination of measles in Europe. Euro surveillance 2009; 14:pii:19443.

146. Riddell MA, Moss WJ, Hauer D, et al. Slow clearance of measles virus RNA after acute infection. J Clin Virol 2007;39:312-317.

147. Rota JS, Wang ZD, Rota PA, et al. Comparison of sequences of the $\mathrm{H}, \mathrm{F}$, and $\mathrm{N}$ coding genes of measles virus vaccine strains. Virus Res 1994;31:317-330.

148. Rota PA, Brown K, Mankertz A, et al. Global distribution of measles genotypes and measles molecular epidemiology. J Infect Dis 2011;204 Suppl 1:S514-S523.
149. Russell SJ, Federspiel MJ, Peng KW, et al. Remission of disseminated cancer after systemic oncolytic virotherapy. Mayo Clin Proc 2014;89:926-933.

150. Sabin AB, Fernandez de Castro J, Flores Arechiga A, et al. Clinical trials of inhaled aerosol of human diploid and chick embryo measles vaccine. Lancet 1982;2:604.

151. Salmon DA, Haber M, Gangarosa EJ, et al. Health consequences of religious and philosophical exemptions from immunization laws: individual and societal risk of measles. JAMA 1999;282:47-53.

152. Samb B, Aaby P, Whittle HC, et al. Serologic status and measles attack rates among vaccinated and unvaccinated children in rural Senegal. Pediatr Infect Dis J 1995;14: 203-209.

153. Santiago C, Bjorling E, Stehle T, et al. Distinct kinetics for binding of the CD46 and SLAM receptors to overlapping sites in the measles virus hemagglutinin protein. $\mathrm{J}$ Biol Chem 2002;277:32294-32301.

154. Santiago C, Celma ML, Stehle T, et al. Structure of the measles virus hemagglutinin bound to the CD46 receptor. Nature Struc Mol Biol 2010;17:124-129.

155. Schneider U, von Messling V, Devaux P, et al. Efficiency of measles virus entry and dissemination through different receptors. J Virol 2002;76:7460-7467.

156. Schonberger K, Ludwig MS, Wildner M, et al. Epidemiology of subacute sclerosing panencephalitis (SSPE) in Germany from 2003 to 2009: a risk estimation. PLoS One 2013;8:e68909.

157. Schwarz AJ. Preliminary tests of a highly attenuated measles vaccine. Am J Dis Child 1962;103:386-389.

158. Seki F, Someya K, Komase K, et al. A chicken homologue of nectin-4 functions as a measles virus receptor. Vaccine 2016;34:7-12.

159. Seya T. Addendum to "Strain-to-strain difference of $\mathrm{V}$ protein of measles virus affects MDA5-mediated IFNbeta-inducing potential" [Mol. Immunol. 48(4) (2011) 497-504]. Mol Immunol 2011;48:1589-1590.

160. Sharma LB, Ohgimoto S, Kato S, et al. Contribution of matrix, fusion, hemagglutinin, and large protein genes of the CAM-70 measles virus vaccine strain to efficient growth in chicken embryonic fibroblasts. J Virol 2009;83: 11645-11654.

161. Shibahara K, Hotta H, Katayama $Y$, et al. Increased binding activity of measles virus to monkey red blood cells after long-term passage in Vero cell cultures. J Gen Virol 1994;75:3511-3516.

162. Shingai M, Ayata M, Ishida $H$, et al. Receptor use by vesicular stomatitis virus pseudotypes with glycoproteins of defective variants of measles virus isolated from brains of patients with subacute sclerosing panencephalitis. J Gen Virol 2003;84:2133-2143.

163. Shingai M, Ebihara T, Begum NA, et al. Differential type I IFN-inducing abilities of wild-type versus vaccine strains of measles virus. J Immunol 2007;179:6123-6133.

164. Shivakoti R, Hauer D, Adams RJ, et al. Limited in vivo production of type I or type III interferon after infection of macaques with vaccine or wild-type strains of measles virus. J Interferon Cytokine Res 2015;35:292-301.

165. Shivakoti R, Siwek M, Hauer D, et al. Induction of dendritic cell production of type I and type III interferons by wild-type and vaccine strains of measles virus: role of defective interfering RNAs. J Virol 2013;87:7816-7827.

166. Simons E, Ferrari M, Fricks J, et al. Assessment of the 2010 global measles mortality reduction goal: results from 
a model of surveillance data. Lancet 2012;379:21732178.

167. Stebbings $\mathrm{R}$, Fevrier M, Li B, et al. Immunogenicity of a recombinant measles-HIV-1 clade $B$ candidate vaccine. PLoS One 2012;7:e50397.

168. Tahara M, Takeda M, Seki F, et al. Multiple amino acid substitutions in hemagglutinin are necessary for wild-type measles virus to acquire the ability to use receptor CD46 efficiently. J Virol 2007;81:2564-2572.

169. Tahara M, Takeda M, and Yanagi Y. Contributions of matrix and large protein genes of the measles virus Edmonston strain to growth in cultured cells as revealed by recombinant viruses. J Virol 2005;79:15218-15225.

170. Takahashi H, Umino Y, Sato TA, et al. Detection and comparison of viral antigens in measles and rubella rashes. Clin Infect Dis 1996;22:36-39.

171. Takaki H, Watanabe Y, Shingai M, et al. Strain-to-strain difference of $\mathrm{V}$ protein of measles virus affects MDA5mediated IFN-beta-inducing potential. Mol Immunol 2011;48:497-504.

172. Takeda M, Kato A, Kobune F, et al. Measles virus attenuation associated with transcriptional impediment and a few amino acid changes in the polymerase and accessory proteins. J Virol 1998;72:8690-8696.

173. Takeda M, Ohno S, Tahara M, et al. Measles viruses possessing the polymerase protein genes of the Edmonston vaccine strain exhibit attenuated gene expression and growth in cultured cells and SLAM knock-in mice. J Virol 2008;82:11979-11984.

174. Takeda M, Sakaguchi T, Li Y, et al. The genome nucleotide sequence of a contemporary wild strain of measles virus and its comparison with the classical Edmonston strain genome. Virology 1999;256:340-350.

175. Takeuchi K, Miyajima N, Kobune F, et al. Comparative nucleotide sequence analyses of the entire genomes of B95a cell-isolated and vero cell-isolated measles viruses from the same patient. Virus Genes 2000;20:253-257.

176. Takeuchi K, Nagata N, Kato SI, et al. Wild-type measles virus with the hemagglutinin protein of the Edmonston vaccine strain retains wild-type tropism in macaques. J Virol 2012;86:3027-3037.

177. Tatsuo H, Ono N, Tanaka K, et al. SLAM (CDw150) is a cellular receptor for measles virus. Nature 2000;406: 893-897.

178. Tran-Van H, Avota E, Bortlein C, et al. Measles virus modulates dendritic cell/T-cell communication at the level of plexinA1/neuropilin-1 recruitment and activity. Eur $\mathrm{J}$ Immunol 2011;41:151-163.

179. Uzicanin A, and Zimmerman L. Field effectiveness of live attenuated measles-containing vaccines: a review of published literature. J Infect Dis 2011;204 Suppl 1:S133S148.
180. Valsamakis A, Auwaerter PG, Rima BK, et al. Altered virulence of vaccine strains of measles virus after prolonged replication in human tissue. J Virol 1999;73:87918797.

181. van Binnendijk RS, van der Heijden RW, van Amerongen $\mathrm{G}$, et al. Viral replication and development of specific immunity in macaques after infection with different measles virus strains. J Infect Dis 1994;170:443-448.

182. Vongpunsawad S, Oezgun N, Braun W, et al. Selectively receptor-blind measles viruses: identification of residues necessary for SLAM- or CD46-induced fusion and their localization on a new hemagglutinin structural model. J Virol 2004;78:302-313.

183. Weiland T, Lampe J, Essmann F, et al. Enhanced killing of therapy-induced senescent tumor cells by oncolytic measles vaccine viruses. Int J Cancer 2014;134:235-243.

184. Wendorf KA, Winter K, Zipprich J, et al. Subacute sclerosing panencephalitis: the devastating measles complication that might be more common than previously estimated. Clin Infect Dis 2017;65:226-232.

185. Wolfson LJ, Grais RF, Luquero FJ, et al. Estimates of measles case fatality ratios: a comprehensive review of community-based studies. Int J Epidemiol 2009;38:192-205.

186. Xin JY, Ihara T, Komase K, et al. Amino acid substitutions in matrix, fusion and hemagglutinin proteins of wild measles virus for adaptation to vero cells. Intervirology 2011;54:217-228.

187. Yanagi Y, Ono N, Tatsuo H, et al. Measles virus receptor SLAM (CD150). Virology 2002;299:155-161.

188. Zhang SC, Cai WS, Zhang Y, et al. Engineered measles virus Edmonston strain used as a novel oncolytic viral system against human neuroblastoma through a CD46 and nectin 4-independent pathway. Cancer Lett 2012;325: 227-237.

189. Zhang SC, Wang WL, Cai WS, et al. Engineered measles virus Edmonston strain used as a novel oncolytic viral system against human hepatoblastoma. BMC Cancer 2012;12:427.

190. Zilliox MJ, Moss WJ, and Griffin DE. Gene expression changes in peripheral blood mononuclear cells during measles virus infection. Clin Vaccine Immunol 2007;14: 918-923.

Address correspondence to: Dr. Diane E. Griffin W. Harry Feinstone Department of Molecular Microbiology and Immunology Johns Hopkins Bloomberg School of Public Health 615 N. Wolfe Street Baltimore, MD 21205

E-mail: dgriffi6@jhu.edu 